\title{
A previously uncharacterized gene stm0551 plays a repressive role in the regulation of type 1 fimbriae in Salmonella enterica serotype Typhimurium
}

Ke-Chuan Wang ${ }^{1}$, Yuan-Hsun Hsu ${ }^{1,2}$, Yi-Ning Huang ${ }^{3}$ and Kuang-Sheng Yeh ${ }^{3 *}$

\begin{abstract}
Background: Salmonella enterica serotype Typhimurium produces surface-associated fimbriae that facilitate adherence of the bacteria to a variety of cells and tissues. Type 1 fimbriae with binding specificity to mannose residues are the most commonly found fimbrial type. In vitro, static-broth culture favors the growth of $S$. Typhimurium with type 1 fimbriae, whereas non-type 1 fimbriate bacteria are obtained by culture on solid-agar media. Previous studies demonstrated that the phenotypic expression of type 1 fimbriae is the result of the interaction and cooperation of the regulatory genes fimZ, fim Y, fimW, and fim $U$ within the fim gene cluster. Genome sequencing revealed a novel gene, stm0551, located between fim $Y$ and fimW that encodes an 11.4-kDa putative phosphodiesterase specific for the bacterial second messenger cyclic-diguanylate monophosphate (c-diGMP). The role of stm0551 in the regulation of type 1 fimbriae in S. Typhimurium remains unclear.

Results: A stm0551-deleted stain constructed by allelic exchange constitutively produced type 1 fimbriae in both static-broth and solid-agar medium conditions. Quantative RT-PCR revealed that expression of the fimbrial major subunit gene, fimA, and one of the regulatory genes, fimZ, were comparably increased in the stm0551-deleted strain compared with those of the parental strain when grown on the solid-agar medium, a condition that normally inhibits expression of type 1 fimbriae. Following transformation with a plasmid possessing the coding sequence of stm0551, expression of fimA and fimZ decreased in the stm0551 mutant strain in both culture conditions, whereas transformation with the control vector PACYC184 relieved this repression. A purified STM0551 protein exhibited a phosphodiesterase activity in vitro while a point mutation in the putative EAL domain, substituting glutamic acid (E) with alanine (A), of STM0551 or a FimY protein abolished this activity.
\end{abstract}

Conclusions: The finding that the stm0551 gene plays a negative regulatory role in the regulation of type 1 fimbriae in S. Typhimurium has not been reported previously. The possibility that degradation of c-di-GMP is a key step in the regulation of type 1 fimbriae warrants further investigation.

Keywords: Salmonella enterica serotype Typhimurium, Type 1 fimbriae, c-di-GMP, Phosphodiesterase

\footnotetext{
* Correspondence: ksyeh@ntu.edu.tw

${ }^{3}$ Department of Veterinary Medicine, School of Veterinary Medicine, College of Bioresources and Agriculture, National Taiwan University, Taipei, Taiwan Full list of author information is available at the end of the article
} 


\section{Background}

Salmonella species are some of the most important food-borne pathogens in the world. Members of the genus Salmonella are gram-negative, facultative anaerobic rods which are composed of more than 2500 serotypes [1]. Salmonella enterica serotype Typhimurium ( $S$. Typhimurium) is an important causative agent for gastroenteritis. For most bacteria, adhesion to host epithelial cells is the first step in establishing an infection. Adhesion proteins or hair-like appendages called fimbriae on the outer membranes of bacteria have been implicated in adherence [2]. Whole-genome sequencing identified 13 separate fimbrial gene clusters that may have the potential to encode fimbria-associated proteins in S. Typhimurium [3]. Among these, type-1 fimbriae are the most commonly found type in $S$. Typhimurium, as in other members of the family Enterobacteriaceae [4]. In addition to adherence, type 1 fimbriae also contribute to virulence and biofilm formation [5-7].

Phenotypic expression of type 1 fimbriae in $S$. Typhimurium involves the interaction and cooperation of genes in the fim gene cluster. Briefly, FimA, FimI, FimF, and FimH are structural proteins that are incorporated to assemble a fimbrial shaft structure, while FimC and FimD proteins located in the periplasmic space and on the outer membrane respectively, function to transport and anchor the fimbrial proteins. FimZ, FimY, FimW, and an arginine transfer RNA fimU, regulate fimbrial production by a complicated network [8-12]. Studies also demonstrated that a global regulator, leucineresponsive regulatory protein (Lrp), and other genes outside the fim gene cluster also take part in the regulatory expression of type-1 fimbriae [13,14].

Bis- $\left(3^{\prime}-5^{\prime}\right)$-cyclic dimeric GMP (c-di-GMP) is a universal second messenger that controls cell surface-associated characters in bacteria [15]. Recent studies revealed the importance of c-di-GMP in regulating many physiological process such as adhesion, biofilm formation, exopolysaccharide synthesis, virulence, and motility $[16,17]$. The cellular c-di-GMP concentration is regulated by diguanylate cyclase (DGC) and phosphodiesterase (PDE). DGC catalyzes the formation of c-di-GMP through a linear intermediate, pppGpG, while PDE degrades it into guanosine monophosphate (GMP). The most prominent conserved protein domains in the PDE are EAL and HD-GYP [17]. An open reading frame named stm0551, located between fim $Y$ and fim $W$, has not previously been investigated to determine its involvement in type-1 fimbrial regulation in $S$. Typhimurium (Figure 1). The amino acid sequence of the STM0551 protein could encode a putative PDE. Multiple alignments of the EAL domain of STM0551 with other known PDE enzymes demonstrated the preservation of several regions throughout the domain sequence $>$ (Figure 2). Since STM 3611 influences curli fimbrial expression in $S$.
Typhimurium, and MrkJ controls type 3 fimbriae production and biofilm formation in Klebsiella pneumoniae $[18,19]$, we decided to investigate whether stm0551 encodes a functional PDE that plays a role in type 1 fimbrial expression.

In the present study, a stm0551 mutant was constructed by allelic exchange. Phenotypic and genotypic characteristics of this mutant were analyzed. Purified STM0551 protein was tested for its putative function as a PDE in vitro. A possible role of stm0551 in type 1 fimbrial regulation in $S$. Typhimurium is discussed.

\section{Results}

\section{Type 1 fimbrial expression by the $S$. Typhimurium stm0551 mutant strain}

The bacterial strains and plasmids used were described in Table 1, while the primers used was indicated in Table 2. The $S$. Typhimurium stm0551 knockout mutant strain was constructed by a one-step gene inactivation method [20]. Primers stm0551-F and stm0551-R external to stm0551 amplified a 0.5-kb DNA fragment from $S$. Typhimurium LB5010 genomic DNA, while the same primer set generated a $1.3-\mathrm{kb}$ DNA fragment from genomic DNA of the $S$. Typhimurium stm0551 mutant strain, indicating a kanamycin cassette inserted into the stm0551 gene. This DNA fragment was also sequenced to determine its identity. The confirmed stm0551 mutant strain was then designated $S$. Typhimurium $\Delta s t m 0551$. S. Typhimurium LB5010 mediated yeast agglutination and guinea pig erythrocyte when cultured in static LB broth, whereas agglutination was not detected when cells were collected from LB agar (Table 3). In contrast, the $S$. Typhimurium $\Delta s t m 0551$ strain mediated agglutination when grown on LB agar. Nonetheless the degree of agglutination was not as strong as the same strain grown in static LB broth. Transformation of the pSTM0551 plasmid that contains the coding sequence of stm0551 conferred on S. Typhimurium $\Delta s t m 0551$ strain the ability to inhibit type 1 fimbrial expression in both culture conditions, while the $S$. Typhimurium $\Delta s t m 0551$ strain carrying a plasmid that possessed a stm0551 coding sequence with the glutamic acid (E) at position 49 replaced with an alanine (A), or a pACYC184 cloning vector exhibited the same phenotype as the $S$. Typhimurium $\Delta s t m 0551$ strain. The Figure 3 demonstrated the yeast agglutination tests performed on glass slides.

\section{Electron microscopy}

$S$. Typhimurium LB5010 prepared in static LB broth culture demonstrated fimbrial appendages on the outermembrane of the cell (Figure 4, panel A). On the contrary, S. Typhimurium LB5010 grown on agar medium did not produce type1 fimbriae (Figure 4, panel 


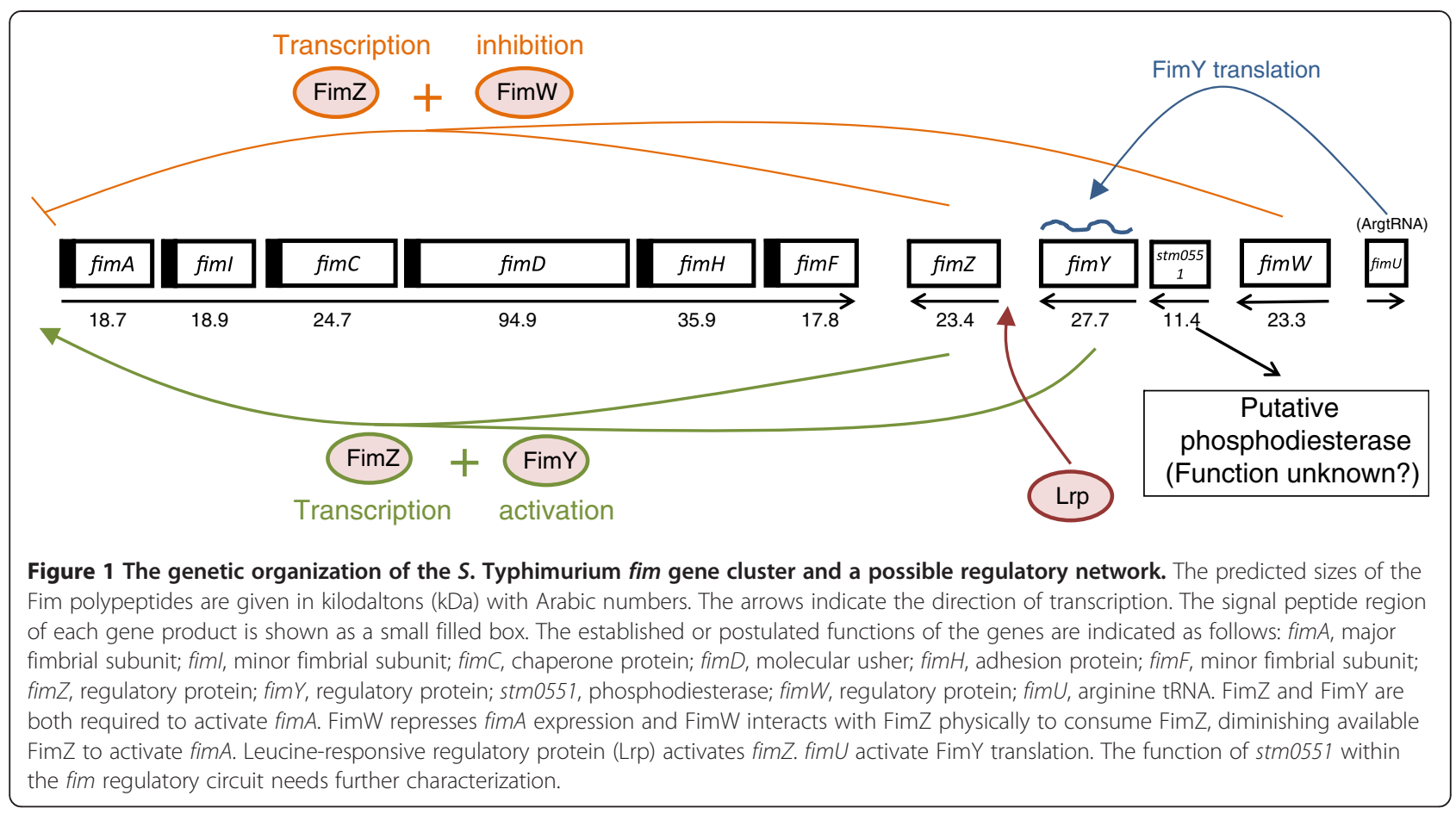

B). The $S$. Typhimurium $\Delta s t m 0551$ strain prepared from static broth medium (Figure 4, panel C) or agar (Figure 4, panel D) produced fimbrial structures.

\section{Quantitative RT-PCR analysis}

Total RNA from LB5010, $\Delta$ stm0551, $\Delta$ stm0551 (pSTM0551), and $\Delta$ stm0551 (pACYC184) strains were prepared and analyzed for the fimbrial subunit gene, $\operatorname{fim} A$, and the regulatory genes, $\operatorname{fim} Z, \operatorname{fim} Y$, and $\operatorname{fim} W$, by quantitative RT-PCR. $16 \mathrm{~S}$ ribosomal (r) RNA expression was used as a control. Individual gene expression profiles were first normalized against the $16 \mathrm{~S}$ rRNA gene and then compared to the expression level of $\operatorname{im} A$, fim $Z$, fim $Y$, and $\operatorname{fim} W$ obtained from agar. As for the parental LB5010 strain, fimA expression obtained from static LB broth was about 150-fold higher than the value obtained from LB agar. The fimA expression of the $\Delta$ stm0551 strain grown on agar was significantly higher than that of LB5010 grown on agar. Transformation of $\Delta s t m 0551$ with a plasmid possessing the stm0551 coding sequence repressed fimA expression whether this strain was cultured on agar or in static broth, whereas transformation of the same bacterial strain with the plasmid cloning vector $\mathrm{pACYC} 184$ de-repressed fimA expression in both culture conditions (Figure 5, panel A). The fimZ expression levels from different strains demonstrated a similar profile to that observed for fimA. The parental LB5010 strain exhibited significant elevated level of fimZ when grown in broth than on agar. The fim $Z$ expression of $\Delta s t m 0551$ was higher than that of the parental strain grown on agar. Transforming $\Delta s t m 0551$ with pSTM0551 repressed fim $Z$ expression on both culture conditions, while transforming $\Delta s t m 0551$ with pACYC184 cloning vector de-repressed fim $Z$ expression, leading to comparable level of expression as seen in the $\Delta s t m 0551$ strain (Figure 5, panel B). However, the expression levels of fim $Y$ were not significantly different between strains under both growth conditions (Figure 5, panel C). $\Delta s t m 0551$ (pACYC184) had higher fim $W$ expression than $\Delta s t m 0551$ (pSTM0551) did when both strains were culture on agar medium (Figure 5, panel D).

\section{PDE activity}

Since the predicted amino acid sequence of STM0551 suggested that it was related to a family of proteins that exhibit PDE activity, we determined whether STM0551 possessed PDE activity. The in vitro PDE activity of the purified STM0551-His fusion protein was determined using the specific substrate, bis ( $p$ NPP). The purified FimY-His fusion protein was used as a control since FimY amino acids exhibited no domain related to PDE activity. STM0551 possesses "EVL" conserved residues that may form the putative active site that varies from the consensus "EAL" sequence. We constructed a substitution mutation in which the glutamic acid (E) at position 49 was replaced by alanine (A) in the stm0551 allele. A fusion protein of this construct was prepared with the same procedure described for STM0551 and FimY and was designed as STM0551E49A-His. The reactions that contained STM0551 exhibited a statistically significant 1.75- 
fold increase in the release of $p$-nitrophenol compared to that containing FimY and STM0551E49A (both reaction mixtures contained the same amount of protein [10 $\mu \mathrm{g}]$ ) (Figure 6). This result suggests that STM0551 could function as a PDE.

\section{Discussion}

The regulatory pathway of type 1 fimbriae in $S$. Typhimurium involves several genes including the fim gene cluster and other genes such as lrp [8-14]. The Salmonella pathogenicity island 1 (SPI1) and flagellar systems also crosstalk with type 1 fimbriae [23]. Several studies have indicated that the mechanism controlling the intracellular c-diGMP concentration plays a critical role in regulating fimbrial production. For example, MrkJ, a PDE, regulates type-3 fimbrial production in Klebsiella pneumoniae [19].
Deletion of $m r k J$ resulted in an increase in type-3 fimbrial production [19]. In Escherichia coli S fimbriae are regulated by a PDE, SfaY [24]. Production of CupA fimbriae of Pseudomonas aeruginosa is controlled by both the GGDEF domain in protein, PA1120, and PvrR that contains an EAL domain [25]. The FimK of Klebsiella pneumoniae contains the EAL domain and deletion of fimK conferred hyperpiliation of type 1 fimbriae in this bacterium [26]. Our present finding may add one more example to this fimbrial regulation/c-di-GMP concentration circuit.

The stm0551 gene of $S$. Typhimurium is located within the fim gene cluster but has not previously been investigated. The predicted amino acids of STM0551 showed similarity to those of proteins with PDE activity, so it was interesting to further dissect the function of stm0551 in terms of type 1 fimbrial regulation. The parental strain $S$. 
Table 1 Bacterial strains and plasmids used in this study

\begin{tabular}{|c|c|c|}
\hline Name & Description $^{a}$ & Reference or source \\
\hline \multicolumn{3}{|c|}{ Salmonella enterica serotype Typhimurium } \\
\hline LB5010 & $\begin{array}{l}\text { Wild type S. enterica serotype Typhimurium LT2 } \\
\text { strain, fimbriate with the complete fim gene cluster }\end{array}$ & {$[21]$} \\
\hline$\Delta$ stm0551 & stm0551 deletion mutant; Kan ${ }^{r}$ & Present study \\
\hline \multicolumn{3}{|l|}{ Escherichia coli strain } \\
\hline $\begin{array}{l}\text { One Shot }{ }^{\circledR} \text { TOP } 10 \\
\text { chemically competent E. coli }\end{array}$ & 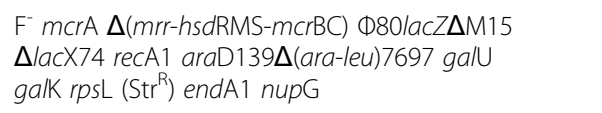 & Invitrogen \\
\hline $\begin{array}{l}\text { BL21Star }^{T M}(D E 3) \text { One Shot } \\
\text { chemically competent E. coli }\end{array}$ & $\mathrm{F}^{-} \mathrm{ompT} h \mathrm{hd} \mathrm{S}_{B}\left(\mathrm{r}_{\mathrm{B}}^{-} \mathrm{m}_{\mathrm{B}}^{-}\right) \mathrm{gal} \mathrm{dcm}(\mathrm{DE} 3)$ & Invitrogen \\
\hline \multicolumn{3}{|l|}{ Plasmids } \\
\hline pSTM0551 & $\begin{array}{l}\text { A } 0.5-\mathrm{kb} \text { DNA fragment possessing the stm0551 } \\
\text { coding sequence cloned into the pACYC184 } \\
\text { vector; } \mathrm{Cm}^{r}\end{array}$ & Present study \\
\hline pSTM0551E49A & $\begin{array}{l}\text { A 0.5-kb DNA fragment possessing the stm0551 } \\
\text { coding sequence with glutamic acid (E) at } \\
\text { position } 49 \text { replaced with an alanine (A) cloned } \\
\text { into the pACYC184 vector; } \mathrm{Cm}^{r}\end{array}$ & Present study \\
\hline pACYC184 & Tet $^{r}, \mathrm{Cm}^{r}$, cloning vector; w/p15A ori & ATCC, Manassas, VA \\
\hline pET101/D-TOPO & $\mathrm{Amp}^{\mathrm{r}}, 6 \mathrm{xH}$ is tag expression vector & Invitrogen \\
\hline pKD46 & $\begin{array}{l}\text { Ampr', express } \lambda \text { Red recombinase system, temp- } \\
\text { sensitive replicon }\end{array}$ & {$[22]$} \\
\hline pKD13 & Plasmid carrying $\operatorname{Kan}^{\mathrm{r}}$ cassette & {$[22]$} \\
\hline
\end{tabular}

${ }^{a} A m p^{r}$ ampicillin resistant; $\mathrm{Cm}^{r}$ chloramphenicol resistant; $\mathrm{Kan}^{r}$ kanamycin resistant; $\mathrm{Tet}^{r}$ tetracycline resistant

Typhimurium LB5010, is an LT2 derivative and displays a variable fimbrial phase [21]. A static broth culture favors $S$. Typhimurium to produce type 1 fimbriae, while nonfimbriae phase bacteria were obtained by growth on solid agar medium [27]. A stm0551 knockout mutant strain constructed in the present study enabled it to produce type 1 fimbriae on the solid LB agar medium. This phenotype was correlated with the RT-PCR result that the mRNA expression of the major fimbrial subunit, fimA, was enhanced on solid-agar culture medium. These suggested that stm0551 plays a repressive role in type 1 fimbrial regulation perhaps in a similar manner to the role played by FimW in the fim regulatory circuit [9]. The expression of fimA of the transformant $\Delta$ stm0551 (pSTM0551) grown on agar decreased to the same level as that of the parental LB5010 strain grown in the same conditions. However, this transformant did not exhibit visible yeast agglutination and guinea pig erythrocyte hemagglutination when grown in static broth, nor did this strain exhibit fimA expression, which was unexpected. One of the reasons could have been the relatively high level of STM0551 production due to presence of the multiple copies of the pSTM0551 recombinant plasmid in these cells. An excessive STM0551 level in S. Typhimurium could presumably cause a dramatically decreased concentration of c-di-GMP locally, and subsequently interfere with fimA expression. However, the mechanism by which
STM0551 interacts with fimA gene expression remains unclear. One possibility is that the stm0551 product maintained the local concentration of c-di-GMP at a level such that only a certain amount of c-di-GMP was bound by a hypothetical PilZ domain containing protein. This low concentration of c-di-GMP-bound, PilZ domain-containing protein was not able to activate fimA gene expression. Disruption of stm0551 increased the local c-di-GMP concentration and consequently also increased the "functional" PilZ domain-containing protein to enhance fimA expression. The FimY protein of $S$. Typhimurium could possibly function as such a PilZ domain-containing protein since recently we found that the amino acid sequence of FimY demonstrated relatedness to those of MrkH of K. pneumoniae and YcgR of the E. coli K-12 strain (data not shown). Both MrkH and YcgR were shown to be transcriptional activators with c-di-GMP-binding PilZ domains [28,29]. Our hypothesis about the role FimY correlates with the finding that STM0551 did not affect fim $Y$ at the transcriptional level (Figure 5, panel C). More detailed study of FimY is necessary to define its role in a possible c-di-GMP regulatory network. Both FimY and FimZ are required to activate fimA expression in S. Typhimurium [8]. FimZ is a DNA binding protein that binds the fimA promoter and activate its expression [30]. Our qRT-PCR results demonstrated very similar profiles for both fimA and fim $Z$ 
Table 2 Primers used in the present study

\begin{tabular}{|c|c|c|}
\hline Purpose and name & Sequence $\left(5^{\prime}\right.$ to $\left.3^{\prime}\right)$ & Description \\
\hline \multicolumn{3}{|c|}{ Construction of the stm0551 mutant } \\
\hline stm0551pKD13-F & $\begin{array}{l}\text { GCTCTGATGTTTCAATGCCTTCCATCAGC } \\
\text { ATTAACTGATTCCGGGGATCCGTCGACC }\end{array}$ & $\begin{array}{l}\text { Annealing Temp.: } 55^{\circ} \mathrm{C} ; \\
\text { amplicon length: } 1,550 \mathrm{bp}\end{array}$ \\
\hline stm0551pKD13-R & $\begin{array}{l}\text { GGCACAGGGTATTITGTTAAAGGAAAGG } \\
\text { ATAAATCCCTGTAGGCTGGAGCTGCTTCG }\end{array}$ & \\
\hline \multicolumn{3}{|l|}{ Cloning } \\
\hline stm0551-F & GGATCCCATCCTGCTIITTCCATTGCTCTAATAT & BamHI restriction site (underlined) \\
\hline \multirow[t]{2}{*}{ stm0551-R } & GATATCACTCACTTAACTTITTACAAGGCTTACG & EcoRV restriction site (underlined) \\
\hline & & $\begin{array}{l}\text { Annealing Temp.: } 55^{\circ} \mathrm{C} \text {; amplicon } \\
\text { length: } 500 \mathrm{bp}\end{array}$ \\
\hline \multicolumn{3}{|c|}{ Construction of the fusion protein } \\
\hline stm0551-TOPO-F & CACCATGGTGGCACAGGGTATTTGTTAA & $\begin{array}{l}\text { Annealing Temp:: } 50^{\circ} \mathrm{C} \text {; amplicon } \\
\text { length: } 316 \text { bp }\end{array}$ \\
\hline stm0551-TOPO-R & ATATATATCTGGTAATATGGCTGG & \\
\hline fimY-TOPO-F & CACCATGCGCAGCGTACCACGCAG & $\begin{array}{l}\text { Annealing Temp:: } 50^{\circ} \mathrm{C} \text {; amplicon } \\
\text { length: } 727 \mathrm{bp}\end{array}$ \\
\hline fimY-TOPO-R & AAAAATGTCGTGGAAAGTAACGT & \\
\hline E49A-TOPO-F & ATCGGCTATGCGGTCCTGACGCAACTTCCG & Mutation site (underlined) \\
\hline E49A-TOPO-R & CGGAAGTTGCGTCAGGACCGCATAGCCGAT & Mutation site (underlined) \\
\hline \multicolumn{3}{|l|}{ RT-PCR analysis } \\
\hline fimA-RT-F & ACTATTGCGAGTCTGATGTTTG & \\
\hline fimA-RT-R & CGTATTTCATGATAAAGGTGGC & \\
\hline fimZ-RT-F & ATTCGTGTGATTTGGCGT & \\
\hline fimZ-RT-R & ACTTATCCTGTTGACCTT & \\
\hline fimY-RT-F & GAGTTACTGAACCAACAGCT & \\
\hline fimY-RT-R & GCCGGTAAACTACACGATGA & \\
\hline fimW-RT-F & AAAGTGAAAGTAAAGCGG & \\
\hline fimW-RT-R & AAGAGATAGATAATGCCCG & \\
\hline stm0551-RT-F & GCCATAAATAACCTTGTTCC & \\
\hline stm0551-RT-R & CATTCATATCTCAACAGCGA & \\
\hline $16 s-F$ & TTCCTCCAGATCTCTACGCA & \\
\hline $16 s-R$ & GTGGCTAATACCGCATAACG & \\
\hline
\end{tabular}

Table 3 Phenotypic expression of type 1 fimbriae in S. Typhimurium

\begin{tabular}{llll}
\hline Strain & Plasmid transformed & \multicolumn{2}{l}{$\begin{array}{l}\text { Phenotypic expression of } \\
\text { type-1 fimbriae }\end{array}$} \\
\hline & & agar & broth \\
LB5010 & none & - & ++ \\
$\Delta s t m 0551$ & none & + & ++ \\
$\Delta s t m 0551$ & pSTM0551 & - & - \\
$\Delta s t m 0551$ & pSTM0551E49A & + & ++ \\
$\Delta s t m 0551$ & pACYC184 & + & ++ \\
\hline
\end{tabular}

a Phenotypic expression of type-1 fimbriae was determined using a mannosesensitive yeast agglutination test and guinea pig erythrocyte hemagglutination test expression (Figure 5, panel A and B). According to the results reported by Saini et al., FimY and FimZ independently activate the fimA gene expression, in addition, FimY and FimZ also activated each other's expression [31]. Inactivation of stm0551 could possibly increase the local concentration of c-di-GMP, which results more c-di-GMP bound FimY (active form) available to activate fim $Z$ and fim $A$, and eventually amplifies the fim $A$ expression. FimW is a repressor for fim $A$ in $S$. Typhimurium. FimW may achieve this repressive role by repressing fim $Y$ transcription or by protein-protein interaction with FimZ [9,31]. In the present study, little information was obtained regarding how stm0551 may interact with fim W. 


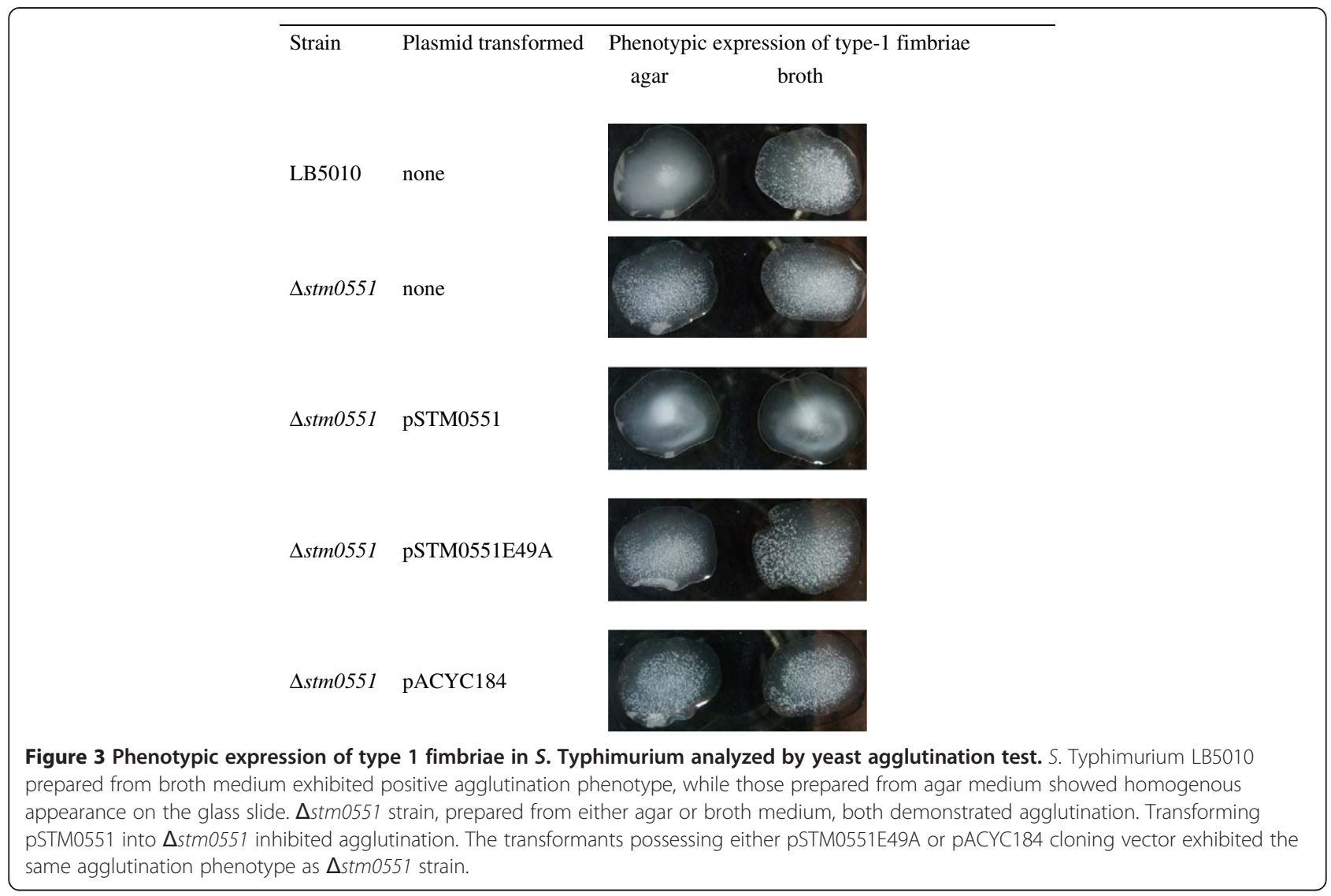

The purified STM0551 fusion protein possessed the ability to cleave the PDE-specific substrate, bis ( $p \mathrm{NPP})$, in vitro, thus confirming the putative phosphodiesterase function assigned to it in the current databank. The construct STM0551E49A-His contained a point mutation in which the conserved glutamic acid residue at position 49

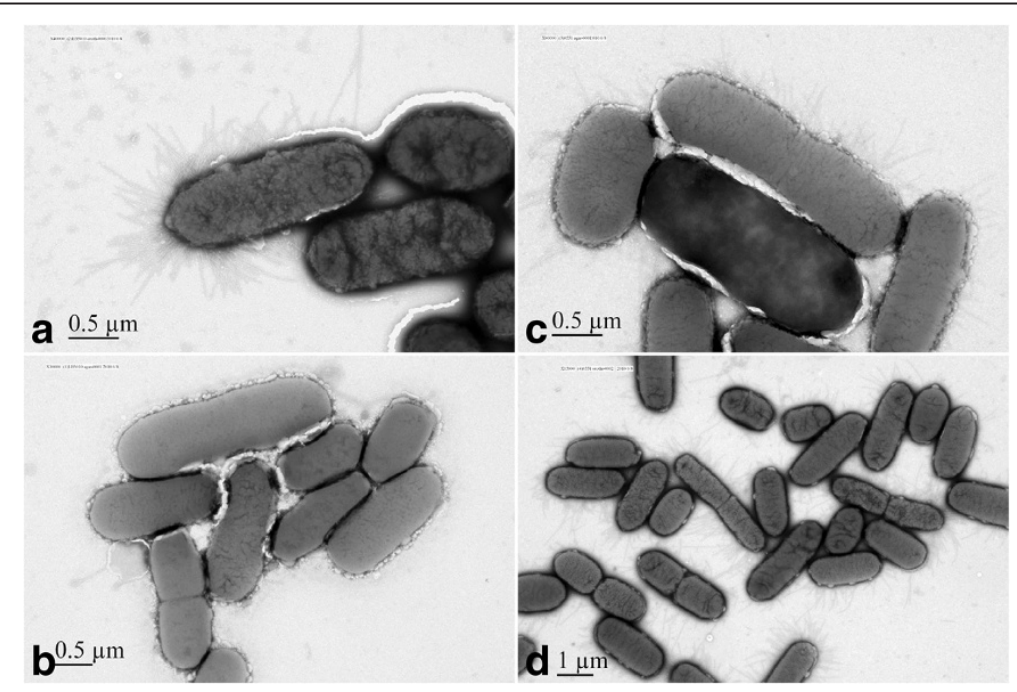

Figure 4 Observation of S. Typhimurium LB5010 and the S. Typhimurium $\Delta$ stm0551 strain by electron microscopy. Panel A: S. Typhimurium LB5010 obtained following growth under static LB broth conditions at $37^{\circ} \mathrm{C}$ for $48 \mathrm{~h}$ produced type 1 fimbrial appendages $(40,000 \times)$. Panel B: No fimbrial structures were observed on the S. Typhimurium LB5010 grown on LB agar at $37^{\circ} \mathrm{C}$ for $18 \mathrm{hr}(30,000 \times)$. Panel C: S. Typhimurium $\Delta$ stm0551 cells obtained from static LB broth condition at $37^{\circ} \mathrm{C}$ for $48 \mathrm{~h}$ produced type 1 fimbrial appendages $(15,000 \times)$ whereas the fimbrial appendages were also observed when these cells were cultured on LB solid agar (panel D) $(40,000 \times)$. Bacterial cells were negatively stained with $2 \%$ phosphotungstic acid. 


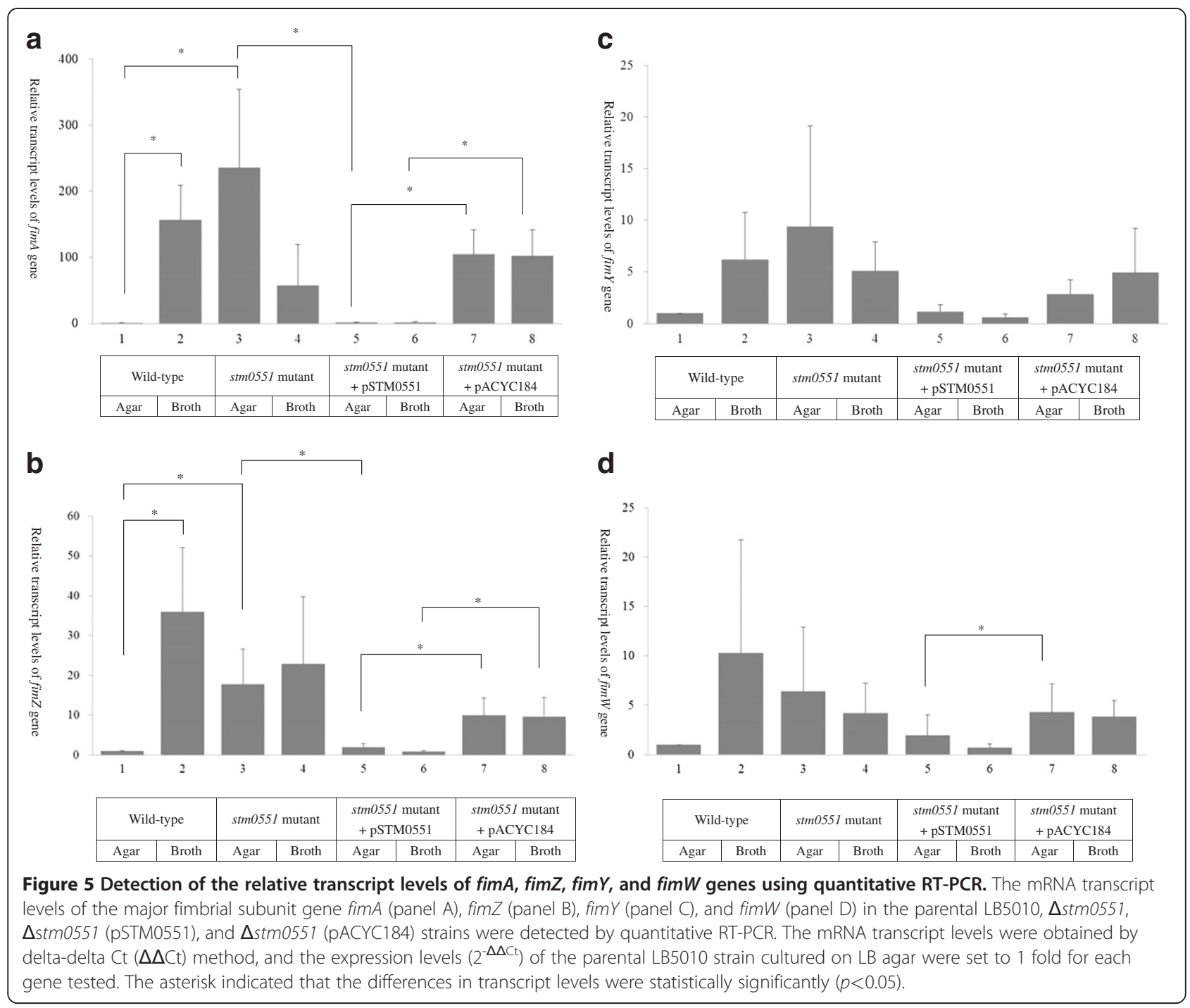

within the putative active site was replaced with an alanine residue; the STM0551E49A mutant protein was unable to cleave bis $(p N P P)$. In accordance with this result, when the STM0551E49A-containg construct cloned into a pACYC184 vector (pSTM0551E49A) was transformed into $\Delta$ stm0551, the resulting transformant exhibited the same phenotype as that of $\Delta s t m 0551$ or $\Delta s t m 0551$ possessing pACYC184 cloning vector (Table 3 ). This further suggested that the glutamic acid at position 49 of STM0551 did play a critical role for phosphodiesterase activity. Therefore, the in vivo agglutination phenotype results correlated with the in vitro phosphodiesterase activity result. In addition, the purified FimY protein, a positive regulator of type 1 fimbriae, also did not demonstrate such activity. Our results indicated that STM0551 has PDE activity in vitro. Currently, we can only say that stm0551 takes part in the complicated type 1 fimbrial regulatory network and play a repressive role. We have no direct evidence about whether stm0551 actually modulates the concentration of the c-di-GMP pool in $S$. Typhimurium to achieve its impact on fim gene regulation. Although the determination of the intracellular concentration of c-di-GMP of $\Delta s t m 0551$ mutants warrants further investigation, this may be prove to be difficult because the c-di-GMP concentration fluctuates locally, due to the spatial compartmentalization of proteins [32]. One example of this phenomenon is that the majority of the c-di-GMP in Acetobacter xylinum is bound by a membrane protein and is released only in response to certain signals [33]; therefore we need to take into consideration that the actual and measured concentrations of cdi-GMP might be different.

Besides fimbrial production, it is interesting to investigate whether stm0551 can influence other phenotypes of $S$. Typhimurium. We tested the ability of bacteria to form biofilm, swimming and swarming motility, and the ability to bind Congo red (rdar morphotype) in the LB5010 and $\Delta s t m 0551$ strains, but both strains exhibited the same phenotype [34,35] (data not shown). In summary, our 


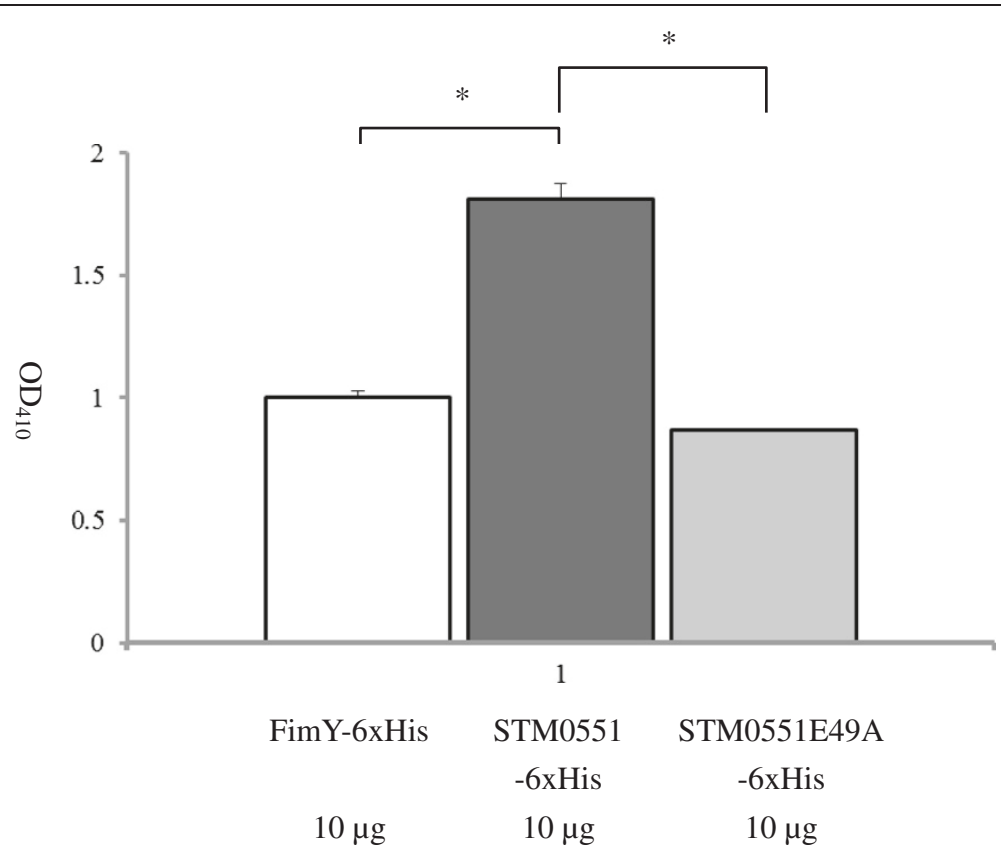

Figure 6 Phosphodiesterase activity. In vitro phosphodiesterase activity assays compared the abilities of the purified STM0551-6xHis, FimY6 XHis, and STM0551E49A-6xHis proteins to cleave the specific substrate, bis ( $p$ NPP). Release of $p$-nitrophenol was determined at $410 \mathrm{~nm}$. ${ }^{*} p<0.05$.

study has suggested for the first time that stm0551 allele which encodes a PDE, play a regulatory role in the production of type 1 fimbriae in $S$. Typhimurium.

\section{Conclusions}

The c-di-GMP pathway is used by most bacteria (but not eukaryotes or Archaea) to regulate numerous biological processes [36]. Several lines of evidence have indicated the concentration of c-di-GMP, balanced by diguanylate cyclase (DGC) and phosphodiesterase (PDE), account for the fimbrial regulatory network in some microorganisms. In $S$. Typhimurium, it has been demonstrated that production of curli fimbriae was inhibited by a PDE STM3611 [18]. However, no other type of fimbrial expression in this microorganism has thus far been shown to be controlled by DGC or PDE. The present study revealed that a previously uncharacterized stm0551 gene, which could encode a PDE, contributes to the down-regulation of type 1 fimbrial expression in $S$. Typhimurium. Our finding may provide valuable information that may help to further elucidate the complicated type 1 fimbrial regulatory circuit in this pathogen.

\section{Methods}

\section{Bacterial strains, plasmids, and culture media}

The bacterial strains, plasmids, and primers used in the present study are listed in Table 1 and Table 2 . The $S$. Typhimurium strain used was LB5010, an LT2 derivative [21]. This strain produces type 1 fimbriae and has a variable fimbrial phase. Bacteria were cultured in Luria-Bertani (LB) broth (Difco/Becton Dickinson, Franklin Lakes, NJ) or plated on LB agar. When required, media were supplemented with antibiotics at the following concentrations: $100 \mu \mathrm{g} / \mathrm{ml}$ ampicillin, $50 \mu \mathrm{g} / \mathrm{ml}$ kanamycin, and $20 \mu \mathrm{g} / \mathrm{ml}$ chloramphenicol. Antibiotics were obtained from Sigma (St. Louis, $\mathrm{MO}$ ). To detect gene expression, $1 \mathrm{mM}$ of isopropyl- $\beta-\mathrm{D}$ -thiogalactopyranoside (IPTG) was used (MDbio, Taipei, Taiwan).

\section{Construction of a S. Typhimurium stm0551 mutant}

A stm0551 mutant was created by one-step gene inactivation method as described previously [20]. Briefly, a kanamycin-resistance gene from pKD13 tagged with a flanking sequence of the stm0551 gene was generated by a polymerase chain reaction (PCR) technique. The designed nucleotide sequence was generated with $P f u$ polymerase (Fermentas, St. Leon-Rot, Germany) on a GeneAmp PCR system 2700 thermal cycler (Applied Biosystems, Foster City, CA) and initially incubated at $94^{\circ} \mathrm{C}$ for $3 \mathrm{~min}$, followed by 30 cycles of $94^{\circ} \mathrm{C}$ for $1 \mathrm{~min}, 50^{\circ} \mathrm{C}$ for $1 \mathrm{~min}$, and $72^{\circ} \mathrm{C}$ for $2 \mathrm{~min}$. Primers used in this approach are listed in Table 3. Then, the PCR product was introduced by electroporation into S. enterica serotype Typhimurium LB5010 possessing the pKD46 plasmid which expressed $\lambda$ Red recombinase [20]. All transformants were grown on LB agar containing kanamycin. The constructed mutants were verified by PCR with primers located in the flanking sequence of the stm0551 gene. 


\section{Yeast agglutination and guinea pig erythrocyte hemagglutination test for type 1 fimbriae}

Tested bacteria were cultured in static LB broth at $37^{\circ} \mathrm{C}$ for $48 \mathrm{~h}$ or on $\mathrm{LB}$ agar at $37^{\circ} \mathrm{C}$ overnight. Bacterial cells in static-broth medium were collected by centrifugation, and the pellet was resuspended in $100 \mu \mathrm{l}$ of $1 \times$ phosphatebuffered saline (PBS). Bacteria from LB agar were scraped with a sterile loop and resuspended in $300 \mu \mathrm{l}$ of $1 \times$ PBS. Subsequently, $30 \mu \mathrm{l}$ of a $3 \%(\mathrm{vol} / \mathrm{vol})$ suspension of Saccharomyces cerevisiae (Sigma) or guinea pig red blood cells in PBS and an equal amount of bacterial cells to be tested were mixed on a glass slide [27]. Visible agglutination after gentle agitation indicated a positive reaction for type 1 fimbriae. The presence of mannose-sensitive yeast cell agglutination or mannose-sensitive guinea pig erythrocyte hemagglutination was determined by mixing the bacterial suspension with PBS containing 3\% (w/v) $\alpha$-methyl-D -mannoside (Sigma).

\section{Electron microscopy}

The bacterial strains tested were grown in static broth or on solid agar and resuspended in $1 \times$ PBS. The bacterial cells were then negatively stained with $2 \%$ phosphotungstic acid and observed with a Hitachi $\mathrm{H}-600$ transmission electron microscope (Hitachi Ltd., Tokyo, Japan).

\section{Complementation test}

Primers used for the complementation test (stm0551-F and stm0551-R) are listed in Table 2 and were used to amplify genomic DNA of $S$. Typhimurium LB5010. The PCR product that possessed the full coding sequence of stm0551 was cloned into the pACYC184 vector using T4 DNA ligase (Fermentas). To construct a stm0551 allele with the glutamic acid at position 49 replaced with an alanine; stm0551-F and E49A-TOPO-R were used to amplify the first DNA fragment using Pfu DNA polymerase (Fermentas). The PCR conditions were: denaturing at $94^{\circ} \mathrm{C}$ for $3 \mathrm{~min}$ followed by 35 cycles of $94^{\circ} \mathrm{C}$ for $45 \mathrm{sec}, 50^{\circ} \mathrm{C}$ for $45 \mathrm{sec}$ and $72^{\circ} \mathrm{C}$ for $45 \mathrm{sec}$. The second DNA fragment was amplified using E49A-TOPO-F and stm0551-R with the same procedure described above. These two DNA fragments were purified by Montage Gel Extraction Kit (Millipore, Billerica, MA). Ligation of these two DNA fragments having two overlapping ends was achieved with stm0551-F and stm0551-R primers as follows: denaturation at $94^{\circ} \mathrm{C}$ for $3 \mathrm{~min}$, ligation at $50^{\circ} \mathrm{C}$ for $45 \mathrm{sec}$ and elongation at $72^{\circ}$ $\mathrm{C}$ for $45 \mathrm{sec}$, followed by 35 cycles of $94^{\circ} \mathrm{C}$ for $45 \mathrm{sec}$., $50^{\circ} \mathrm{C}$ for $45 \mathrm{sec}$, and $72^{\circ} \mathrm{C}$ for $45 \mathrm{sec}$. Amplified DNA fragment was digested with BamHI and EcoRV and cloned into pACYC184 vector to generate pSTM0551E49A. The mutated stm0551 allele of this plasmid was sequenced to confirm if the glutamic acid (E) at position 49 was replaced by alanine (A) before transforming into the $S$. Typhimurium $\Delta s t m 0551$ strain by electroporation. The pACYC184 cloning vector was also transformed into the $S$. Typhimurium $\Delta$ stm0551 strain as a control.

\section{Quantitative RT-PCR analysis}

Total bacterial RNA was isolated using an RNeasy Mini Kit (Qiagen, Hilden, Germany) according to the manufacturer's protocol. Subsequently, RNA was treated with RNase-free DNase (1 unit/1 $\mu \mathrm{g}$ RNA) to remove contaminating genomic DNA. The purified RNA was converted to cDNA using a MMLV reverse transcriptase method in the following steps: First, $100 \mathrm{ng}$ of the total RNA was annealed with $100 \mathrm{nM}$ specific primers by heating to $65^{\circ} \mathrm{C}$ for $2 \mathrm{~min}$ and then cooled on ice for 1 min. Next, $1 \mathrm{U}$ of RNasin, $2 \mu \mathrm{l}$ of $100 \mathrm{mM}$ DTT, $1 \mu \mathrm{l}$ of $10 \mathrm{mM}$ dNTP and $0.5 \mu \mathrm{l}$ of $200 \mathrm{U} / \mu \mathrm{l}$ MMLV High Performance Reverse Transcriptase (Epicentre, Madison, WI) were added to each RNA/primer mixture and incubated at $37^{\circ} \mathrm{C}$ for $1 \mathrm{~h}$, followed by heating at $85^{\circ} \mathrm{C}$ for $10 \mathrm{~min}$ to inactivate the enzyme and then chilled on ice for at least $1 \mathrm{~min}$. The specific cDNA that we prepared was used in the following quantitative real-time PCR analysis. The components of real-time PCR were prepared by adding $10 \mathrm{ng}$ of each specific cDNA and $1 \mu \mathrm{l}$ of a $10 \mathrm{mM}$ primer solution to $2 \times$ Maxima SYBR Green/ ROX qPCR Master Mix (Fermentas) and adjusted with $\mathrm{ddH}_{2} \mathrm{O}$ to a final volume of $20 \mu \mathrm{l}$. Cycling conditions were performed using Roche LightCycler 2.0 system (Roche Applied Science, Branford, CT) as follows: $95^{\circ} \mathrm{C}$ for $2 \mathrm{~min}$ followed by 40 cycles of $95^{\circ} \mathrm{C}$ for $30 \mathrm{sec}, 50^{\circ} \mathrm{C}$ for $30 \mathrm{sec}$ and $72^{\circ} \mathrm{C}$ for $15 \mathrm{sec}$. Dissociation curves and non-template controls were included to detect any primer dimerization or other artifacts. The mRNA transcript levels were obtained by the method described by Livak and Schmittgen [37].

\section{Fusion protein construction}

A carboxy terminal $6 \times$ histidine-tagged fusion to STM0551 was constructed by amplifying stm0551 with primers stm0551-TOPO-F and stm0551-TOPO-R using genomic DNA of S. Typhimurium LB5010 as the template. The resulting 316-bp PCR product was cloned into the pET101/D-TOPO vector (Invitrogen, Carlsbad, CA) giving rise to plasmid pSTM0551-His. This recombinant plasmid was sequenced at the adjacent portion of the cloning site to make sure it was in frame before subsequent transformation step. BL21Star ${ }^{\mathrm{Tm}}$ (DE3) One Shot ${ }^{\circledR}$ chemically competent $E$. coli (Invitrogen) cells were transformed with pSTM0551-His. Log phase cultures were induced to express STM0551-His by adding $1 \mathrm{mM}$ IPTG at $37^{\circ} \mathrm{C}$ for $4 \mathrm{hr}$. The STM0551-His fusion protein was further purified by ProBond purification kit (Invitrogen) using the protocol provided by the manufacturer. The protein concentration was determined using the Bradford reagent (Fermentas) [38]. A mutant allele of stm0551 was constructed by site- 
directed mutagenesis using overlapping-extension PCR of S. Typhimurium LB5010 strain genomic DNA template and mutagenic oligonucleotides E49A-TOPO-F and E49ATOPO-R [39]. Briefly, STM0551-TOPO-F and E49ATOPO-R were used to amplify the first DNA fragment using Pfu DNA polymerase (Fermentas). The PCR conditions were: denaturing at $94^{\circ} \mathrm{C}$ for $3 \mathrm{~min}$ followed by 35 cycles of $94^{\circ} \mathrm{C}$ for $45 \mathrm{sec}, 50^{\circ} \mathrm{C}$ for $45 \mathrm{sec}$ and $72^{\circ} \mathrm{C}$ for $45 \mathrm{sec}$. The second DNA fragment was amplified using E49A-TOPO-F and STM0551-TOPO-R with the same procedure described above. These two DNA fragments were purified by Montage Gel Extraction Kit (Millipore, Billerica, MA). Ligation of these two DNA fragments having two overlapping ends was achieved with STM0551TOPO-F and STM0551-TOPO-R primers as follows: denaturation at $94^{\circ} \mathrm{C}$ for $3 \mathrm{~min}$, ligation at $50^{\circ} \mathrm{C}$ for $45 \mathrm{sec}$ and elongation at $72^{\circ} \mathrm{C}$ for $45 \mathrm{sec}$, followed by 35 cycles of $94^{\circ} \mathrm{C}$ for $45 \mathrm{sec}$., $50^{\circ} \mathrm{C}$ for $45 \mathrm{sec}$, and $72^{\circ} \mathrm{C}$ for $45 \mathrm{sec}$. Amplified fragments were cloned into pET101/D-TOPO vector and sequenced to determine if the glutamic acid (E) at position 49 was replaced by alanine (A). The resulting recombinant plasmid was designed as pSTM0551E49A-His. Further protein induction and purification were performed using the same procedure as for STM0551-His fusion protein. Similarly FimY-His fusion protein was constructed using fimY-TOPO-F and fimY-TOPO-R primers.

\section{PDE activity assay}

In vitro PDE activity assays were performed using purified STM0551-His, STM0551E49A-His and FimY-His proteins. Test protein was suspended in the assay buffer (50 mM Tris- $\mathrm{HCl}$ and $1 \mathrm{mM} \mathrm{MnCl} 2, \mathrm{pH}$ 8.5) supplemented with $5 \mathrm{mM}$ bis ( $p$-nitrophenol) phosphate (bis$p \mathrm{NPP})$ as previously described $[40,41]$. Reactions were incubated at $37^{\circ} \mathrm{C}$ overnight. The release of $p$-nitrophenol was quantified at $\mathrm{OD}_{410}$ in a spectrophotometer (WPA Biowave II, Cambridge, UK).

\section{Statistical analysis}

All statistical data were analyzed using Student's $t$-test. Differences in measurements with a $p$ value of $<0.05$ were considered to be significant.

\section{Authors' contributions \\ The authors have no competing interests. K.-C. Wang drafted the manuscript and performed mutant strain construction and PDE assay. Y.-H. Hsu helped the experimental design and data analysis. Y.-N. Huang assisted molecular cloning and site-directed mutagenesis, protein purification experiments. K.-S. Yeh conceived and coordinated this study and also helped to draft the manuscript. All authors read and approved the final manuscript.}

\section{Acknowledgements}

This study was supported by the National Science Council, Taiwan under contract no. NSC98-2313-B-038-001-MY3. We would like to thank Dr. ChingHao Teng from National Cheng-Kung University, Taiwan for providing pKD46 and pKD13 plasmids. We would also like to thank Ms. S.-T. Kuo from the Animal Health Research Institute, Council of Agriculture, Taiwan for assistance with electron microscopy.

\section{Author details}

${ }^{1}$ Graduate Institute of Medical Sciences, College of Medicine, Taipei Medical University, Taipei, Taiwan. ${ }^{2}$ Department of Microbiology and Immunology, School of Medicine, College of Medicine, Taipei Medical University, Taipei,

Taiwan. ${ }^{3}$ Department of Veterinary Medicine, School of Veterinary Medicine, College of Bioresources and Agriculture, National Taiwan University, Taipei, Taiwan.

Received: 13 March 2012 Accepted: 7 June 2012

Published: 20 June 2012

\section{References}

1. Mead PS, Slutsker L, Dietz V, McCaig LF, Bresee J, Shapiro C, Griffin PM, Tauxe RV: Food-related illness and death in the United States. Emerg Infect Dis 1999, 5:607-625.

2. Duguid JP, Smith IW, Dempster G, Edmunds PN: Non-flagellar filamentous appendages ("fimbriae") and haemagglutinating activity in Bacterium coli. J Pathol Bacteriol 1995, 70:335-348.

3. McClelland M, Sanderson KE, Spieth J, Clifton SW, Latreille P, Courtney L, Porwollik S, Ali J, Dante M, Du F, et al: Complete genome sequence of Salmonella enterica serovar Typhimurium LT2. Nature (London) 2001, 413:852-856.

4. Duguid JP, Gillies RR: Fimbriae and adhesive properties in dysentery bacilli. J Pathol Bacteriol 1957, 74:397-411.

5. Boddicker JD, Ledeboer NA, Jagnow J, Jones BD, Clegg S: Differential binding to and biofilm formation on, HEp-2 cells by Salmonella enterica serovar Typhimurium is dependent upon allelic variation in the fimH gene of the fim gene cluster. Mol Microbiol 2002, 45:1255-1265.

6. van der Velden AWM, Bäumler AJ, Tsolis RM, Heffron F: Multiple fimbrial adhesins are required for full virulence of Salmonella typhimurium in mice. Infect Immun 1998, 66:2803-2808.

7. Tavendale A, Jardine CK, Old DC, Duguid JP: Haemagglutinins and adhesion of Salmonella typhimurium to HEp2 and HeLa cells. J Med Microbiol 1983, 16:371-380.

8. Yeh KS, Hancox LS, Clegg S: Construction and characterization of a fimZ mutant of Salmonella typhimurium. J Bacteriol 1995, 177:6861-6865.

9. Tinker JK, Hancox LS, Clegg S: FimW is a negative regulator affecting type 1 fimbrial expression in Salmonella enterica serovar Typhimurium. J Bacteriol 2001, 183:435-442.

10. Tinker JK, Clegg S: Control of FimY translation and type 1 fimbrial production by the arginine tRNA encoded by fimU in Salmonella enterica serovar Typhimurium. Mol Microbiol 2001, 40:757-768.

11. Swenson DL, Kim KJ, Six EW, Clegg S: The gene fimU affects expression of Salmonella typhimurium type 1 fimbriae and is related to the Escherichia coli tRNA gene argU. Mol Gen Genet 1994, 244:216-218.

12. Swenson DL, Clegg S: Identification of ancillary fim genes affecting fimA expression in Salmonella typhimurium. J Bacteriol 1992, 174:7697-7704.

13. Chuang Y-C, Wang K-C, Chen Y-T, Yang C-H, Men S-C, Fan C-C, Chang L-H, Yeh K-S: Identification of the genetic determinants of Salmonella enterica serotype Typhimurium that may regulate the expression of the type 1 fimbriae in response to solid agar and static broth culture conditions. BMC Microbiol 2008, 8:126.

14. McFarland KA, Lucchin S, Hinton JCD, Dorman CJ: The leucine-responsive regulatory protein, Lrp, activates transcription of the fim operon in Salmonella enterica serovar Typhimurium via the fimZ regulatory gene. J Bacteriol 2008, 190:602-612.

15. Schirmer T, Jenal U: Structural and mechanistic determinants of c-di-GMP signalling. Nature Rev Microbiol 2009, 7:724-735.

16. Jenal U: Cyclic di-guanosine-monophosphate comes of age: a novel secondary messanger involved in modulating cell surface structures in bacteria? Curr Opin Microbiol 2004, 7:185-191.

17. Pesavento $C$, Hengge R: Bacterial nucleotide-based second messangers. Curr Opin Microbiol 2009, 12:170-176.

18. Simm R, Lusch A, Kader A, Andersson M, Romling U: Role of EALcontaining proteins in multicellular behavor of Salmonella enterica serovar Typhimurium. J Bacteriol 2007, 189:3613-3623.

19. Johnson JG, Clegg S: Role of MrkJ, a phosphodiesterase, in type 3 fimbrial expression and biofilm formation in Klebsiella pneumoniae. $J$ Bacteriol 2010, 192:3944-3950.

20. Datsenko KA, Wanner BL: One-step inactivation of chromosomal genes in Escherichia coli K-12 using PCR products. Proc Natl Acad Sci U S A 2000, 97:6640-6645. 
21. Bullas $L R$, Ryu Jl: Salmonella typhimurium $L T 2$ strains which are $r^{-} m^{+}$for all three chromosomally located systems of DNA restriction and modification. J Bacterio/ 1983, 156:471-474.

22. Datsenko KA, Wanner BL: One-step inactivation of chromosomal genes in Escherichia coli K-12 using PCR products. Proc Natl Acad Sci U S A 2000 97(12):6640-6645.

23. Saini S, Slauch JM, Aldridge PD, Rao CV: Role of cross talk in regulating the dynamic expression of the flagellar Salmonella pathogenicity island 1 and type 1 fimbrial genes. J Bacteriol 2010, 192:5767-5777.

24. Sjöström AE, Sondén B, Müller C, Rydström A, Dobrindt U, Wai SN, Uhlin $\mathrm{BE}$ : Analysis of the $s \mathrm{faX}_{\|}$locus in the Escherichia coli meningitis isolate IHE3034 reveals two novel regulatory genes within the promoterdistal region of the main S fimbrial operon. Microb Pathog 2009, 46:150-158.

25. Meissner A, Wild V, Simm R, Rohde M, Erck C, Bredenbruch F, Morr M, Romling U, Haussler S: Pseudomonas aeruginosa cupA-encoded fimbriae expression is regulated by a GGDEF and EAL domain-dependent modulation of the intracellular level of cyclic diguanylate. Environ Microbiol 2007, 9:2475-2485.

26. Rosen DA, Pinkner JS, Jones JM, Walker JN, Clegg S, Hultgren SJ: Utilization of an intracellular bacterial community pathway in Klebsiella pneumoniae urinary tract infection and the effects of FimK on type 1 pilus expression. Infect Immun 2008, 76:3337-3345.

27. Old DC, Corneil I, Gibson LF, Thomson AD, Duguid JP: Fimbriation, pellicle formation and the amount of growth of salmonellas in broth. $J$ Gen Microbiol 1968, 51:1-16.

28. Ryjenkov DA, Simm R, Romling U, Gomelsky M: The PilZ domain is a receptor for the second messenger c-di-GMP: The PilZ domain protein YcgR controls motility in enterobacteria. J Biol Chem 2006, 281:30310-30314.

29. Wilksch JJ, Yang J, Clements A, Gabbe JL, Short KR, Cao HW, Cavaliere R, James CE, Whitchurch CB, Schembri MA, et al: MrkH, a novel c-di-GMP -dependent transcriptional activator, controls Klebsiella pneumoniae biofilm formation by regulating type 3 fimbriae expression. PLOS Pathogens 2011, 7(8):e10002204

30. Yeh KS, Tinker JK, Clegg S: FimZ binds the Salmonella typhimurium fimA promoter region and may regulate its own expression with FimY. Microbiol Immunol 2002, 46:1-10

31. Saini S, Pearl JA, Rao CV: Role of FimW, FimY, and FimZ in regulating the expression of type 1 fimbriae in Salmonella enterica serovar Typhimurium. J Bacteriol 2009, 191:3003-3010.

32. Romling U, Gomelsky M, Galperin MY: c-di-GMP: the dawning of a novel bacterial signalling system. Mol Microbiol 2005, 57:629-639.

33. Weinhouse $H$, Sapir S, Amilcam D, Shilo $Y$, Volman G, Ohana P, Benziman M: c-di-GMP-binding protein, a new factor regulating cellulose synthesis in Acetobacter xylinum. FEBS Lett 1997, 416:207-211.

34. Bokranz W, Wang X, Tschape $H$, Romling U: Expression of cellulose and curli fimbriae by Escherichia coli isolated from the gastrointestinal tract. J Med Microbiol 2005, 54:1171-1182.

35. Simm R, Morr M, Kader A, Nimtz M, Romling U: GGDEF and EAL domains inversely regulate cyclic di-GMP levels and transition from sessility to motility. Mol Microbiol 2004, 53:1123-1134.

36. Tamayo R, Pratt JT, Camilli A: Role of cyclic diguanylate in the regulation of bacterial pathogenesis. Annu Rev Microbiol 2007, 61:131-148.

37. Livak KJ, Schmittgen TD: Analysis of relative gene expression data using real-time quantitative PCR and $2^{-\Delta \Delta C t}$ method. Methods 2001, 25:402-408.

38. Bradford MM: A rapid and sensitive method for the quantitation of microgram quantities of protein utilizing the principle of protein-dye binding. Anal Biochem 1976, 72:248-254.

39. Ho SN, Hunt HD, Horton RM, Pullen JK, Pease LR: Site-directed mutagenesis by overlap extension using the polymerase chain reaction. Gene 1989, 77:51-59.

40. Bobrov AG, Kirillina O, Perry RD: The phosphodiesterase activity of the HmsP EAL domain is required for negative regulation of biofilm formation in Yersinia pestis. FEMS Microbiol Lett 2005, 247:123-130.

41. Kuchma SL, Brothers KM, Merritt JH, Liberati NT, Ausubel FM, OToole GA: BifA, a cyclic-Di-GMP phosphodiesterase, inversely regulates biofilm formation and swarming motility by Pseodomonas aeruginosa PA14. J Bacteriol 2007, 189:8165-8178.

doi:10.1186/1471-2180-12-111

Cite this article as: Wang et al: A previously uncharacterized gene stm0551 plays a repressive role in the regulation of type 1 fimbriae in Salmonella enterica serotype Typhimurium. BMC Microbiology 2012 $12: 111$.

\section{Submit your next manuscript to BioMed Central and take full advantage of:}

- Convenient online submission

- Thorough peer review

- No space constraints or color figure charges

- Immediate publication on acceptance

- Inclusion in PubMed, CAS, Scopus and Google Scholar

- Research which is freely available for redistribution 